\title{
CORRELATION BETWEEN ENDOGENOUS SERUM CORTISOL AND CENTRAL SEROUS RETINOPATHY: A CLINICAL STUDY
}

Ruma Das ${ }^{1}$, Chanchal Poddar ${ }^{2}$, Abhisek Mondal ${ }^{3}$, Tshering Wangchuk Bhutia ${ }^{4}$

${ }^{1}$ Associate Professor, Department of Ophthalmology, Silchar Medical College and Hospital, Silchar, Assam.

${ }^{2}$ Registrar, Department of Ophthalmology, Tezpur Medical College and Hospital, Assam.

3 Post Graduate Trainee, Department of Ophthalmology, Silchar Medical College and Hospital, Silchar, Assam.

${ }_{4}^{4}$ Post Graduate Trainee, Department of Ophthalmology, Silchar Medical College and Hospital, Silchar, Assam.

ABSTRACT

\section{AIMS AND OBJECTIVES}

- To measure the serum cortisol level in patients with acute CSR and thereby assess causal relation of steroid in CSR.

- To compare the serum cortisol levels with different clinical parameters of CSR and to prove or refute their association.

\section{METHODS AND MATERIALS}

Prospective study done for 1 year (2013-2014) in the Dept. of Ophthalmology, Silchar Medical College and Hospital, Silchar. Patients included 50 cases (50 eyes) and 50 controls (50 eyes). Visual acuity; Ophthalmoscopic examination; Slit lamp examination; Fluorescein study; Optical Coherence Tomography; Serum Cortisol Estimation were done on all patients. Following the first day of examination, the patients were reviewed at 3 months ( $2^{\text {nd }}$ visit) and 6 months ( $3^{\text {rd }}$ visit). After proper data collection, data analysis was done with GraphPad Instat 3 Software.

\section{RESULTS AND OBSERVATIONS}

$66 \%$ cases are in the $30-39$ years' age group. Out of 50 cases, 43 were males (86\%) and $7(14 \%)$ were females. On comparing the cases and controls for mean serum cortisol levels, statistical significance was obtained with higher values in cases both for the morning $(p=0.001)$ and evening levels $(p=.0048)$ of serum cortisol. No statistical significance in mean serum cortisol level was obtained in either the morning $(\mathrm{p}=0.1078)$ or evening samples ( $\mathrm{p}=0.3957)$ in single leak and multiple leak (on FFA) cases. On OCT, we found mean foveal thickness of $311.32 \mu \mathrm{m}(\mathrm{SD}=130.06)$ at presentation which reduced to $278.9 \mu \mathrm{m}(\mathrm{SD}=80.649)$ at $3 \mathrm{months}$ in patients with CSR.

\section{CONCLUSION}

The above study has well established a positive association of endogenous steroids in the causation of Central Serous Retinopathy, which has implications in the treatment strategies for the disease in future.

\section{KEYWORDS}

Central Serous Retinopathy, Serum Cortisol Level.

HOW TO CITE THIS ARTICLE: Das R, Poddar C, Mondal A, et al. Correlation between endogenous serum cortisol and central serous retinopathy: a clinical study. J. Evolution Med. Dent. Sci. 2016;5(32):1699-1703, DOI: 10.14260/jemds/2016/400

\section{INTRODUCTION}

Central Serous Retinopathy (CSR) is characterized by an idiopathic circumscribed serous retinal detachment, usually confined to the central macula caused by leakage of fluid through the Retinal Pigment Epithelium (RPE) as defined by Fluorescein Angiography.

CSR primarily occurs in healthy people between 25 and 55 years. ${ }^{1}$ Male:Female ratio ranging from $6: 1$ in older studies and less than 3:1 in more recent literature. ${ }^{2}$

Common symptoms of CSR are decreased vision with distortions including metamorphopsia, micropsia, scotoma, chromatopsia and prolonged after-images. Visual acuity in the acute stages ranges from $20 / 20$ to $20 / 200 .{ }^{3}$ It mostly resolves spontaneously in 4-6 months without any permanent sequel.

It seems to be common in conditions associated with stress, strain and associated physical illness, which in turn are associated with increased levels of cortisol. ${ }^{4}$

Financial or Other, Competing Interest: None.

Submission 11-02-2016, Peer Review 21-02-2016,

Acceptance 24-02-2016, Published 19-04-2016.

Corresponding Author:

Dr. Ruma Das,

Green Park, Meherpur,

Silchar, District

Cachar-788015, Assam.

E-mail: d345rumads@gmail.com

DOI: $10.14260 /$ jemds $/ 2016 / 400$
Patients with elevated levels of corticosteroids due to either corticosteroid administration (Inhaled, topical or systemic) or Cushing's syndrome are at an increased risk of developing CSR, thus supporting the association between CSR and steroids.

\section{MATERIALS AND METHODS \\ Aim}

- To measure the serum cortisol level with paired diurnal samples in patients presenting with acute CSR and thereby assess causal relation of steroid in CSR.

- To compare the serum cortisol levels with different clinical parameters of CSR and to prove or refute their association.

This prospective study was done for 1 year (20132014) in the Dept. of Ophthalmology, Silchar Medical College and Hospital, Silchar. The number of patients included were 50 cases (50 eyes) and 50 controls (50 eyes).

\section{CASES \\ Inclusion Criteria}

Age between $20-55$ yrs. males and females both. First attack of CSR with no previous treatment.

\section{Exclusion Criteria}

Other ocular or systemic disease. Any surgery or trauma within 2 weeks of presentation. Receiving any form of local or 
systemic steroids. Obesity. Alcohol abuse or dependence. Major depression (DSM III R criteria).

\section{CONTROLS}

\section{Inclusion Criteria}

Sudden, painless vision loss other than CSR. Presentation within 3 months of onset.

\section{Exclusion Criteria}

Other systemic disease. Any surgery or trauma within 2 weeks of presentation. Receiving any form of local or systemic steroids. Obesity. Alcohol abuse or dependence. Major depression (DSM III R criteria).

Each participant gave written consent before enrolment into the study. Institutional board approval was obtained from the Ethical Committee of our Institution.

\section{Diagnostic Tests Performed}

Visual acuity; Ophthalmoscopic examination; Slit lamp examination; Fluorescein study (Zeiss Fundus Camera, Visucam Lite); Optical Coherence Tomography (3 ${ }^{\text {rd }}$ generation Cirrus Hd Oct (Spectral Domain Technology); Serum Cortisol Estimation (Chemi-luminescent immunoassay method in Beckman Coulter Access 2. Normal range of reference serum cortisol was determined as between 5 and $25 \mu \mathrm{g} / \mathrm{dL} .5$ in the early morning hrs. between 0400 and 1200 hrs. Late afternoon values are about half the morning concentration and are frequently less than $5 \mu \mathrm{g} / \mathrm{dL}$ between 2200 and $0200 \mathrm{hrs}$.)

Following the first day of examination, the patients were reviewed at 3 months (2nd visit) and 6 months (3 $3^{\text {rd }}$ visit).

After proper data collection, data analysis was done with Graph Pad Instat 3 Software.

The results were presented as mean (SD). A chi-square test was used to compare proportions or percentages and the student ' $\mathrm{t}$ ' test to compare numerical values. $\mathrm{P}$ value less than 0.05 was considered statistically significant. Correlations, wherever required were calculated with Pearson's Coefficient (r) along with their significance. Mean serum cortisol (Diurnal) levels were compared between the two groups and $p$ value was calculated. $P$ value was calculated and statistical significance was observed.

\section{RESULTS AND OBSERVATIONS}

1. 33 out of 50 cases are in the 30-39 years' age group (66\%); 13 out of 50 cases were in the $20-29$ years' age group (26\%). Patients above $40 \mathrm{yrs}$. accounted for only 4 cases ( $8 \%$ ), while none were in the age group of $\geq 50$ yrs. Among controls, $42 \%$ patients were in the age group of 30-39 followed by 13 patients in the age range of 20-29 (26\%); 11 patients were in the age group of $40-49$ (22\%) and only 5 controls were above 50 yrs. of age.

2. Out of 50 cases 43 were males (86\%), while females accounted for 7 cases (14\%). Out of 50 controls, 39 were males (78\%) and females were 11 (22\%).

3. 24 cases $(48 \%)$ had a best corrected visual acuity of $6 / 18$ - 6/36; 22 cases (44\%) had a BCVA of $6 / 6-6 / 12$, while 4 cases $(8 \%)$ had BCVA of $\leq 6 / 60$. Maximum controls (30) had a BCVA of $6 / 18-6 / 36(58 \%)$, followed by 11 patients with $6 / 6-6 / 12$ (22\%); 10 cases had a BCVA of less than $6 / 60(20 \%)$.
4. When the cases and controls were compared for mean serum cortisol levels (diurnal samples), statistical significance was obtained with higher values in cases both for the morning $(\mathrm{p}=0.001)$ and evening levels $(\mathrm{p}=.0048)$.

\begin{tabular}{|c|c|c|c|c|}
\hline \multirow{2}{*}{$\begin{array}{l}\text { Sl. } \\
\text { No. }\end{array}$} & \multirow{2}{*}{$\begin{array}{c}\text { Mean Serum } \\
\text { Cortisol } \\
(\mu \mathrm{g} / \mathrm{dL})\end{array}$} & \multicolumn{2}{|c|}{ Sample } & \multirow{2}{*}{$P$ Value } \\
\hline & & Cases & Controls & \\
\hline 1 & Morning & $\begin{array}{c}21.8214 \\
(\mathrm{SD}=4.145)\end{array}$ & $\begin{array}{c}19.3866 \\
(\mathrm{SD}=2.947)\end{array}$ & 0.001 \\
\hline 2 & Evening & $\begin{array}{c}13.5438 \\
(\mathrm{SD}=2.99)\end{array}$ & $\begin{array}{c}11.8276 \\
(S D=2.963)\end{array}$ & 0.0048 \\
\hline
\end{tabular}

5. Mean serum cortisol levels were compared between single leak and multiple leaks as obtained on FFA and no statistical significance was obtained in either the morning $(p=0.1078)$ or evening samples $(p=0.3957)$.

\begin{tabular}{|c|c|c|c|c|c|}
\hline $\begin{array}{c}\text { Sl. } \\
\text { No. }\end{array}$ & Variable & $\begin{array}{c}\text { Single } \\
\text { Leak }\end{array}$ & $\begin{array}{c}\text { Multiple } \\
\text { Leak }\end{array}$ & $\begin{array}{c}\text { P } \\
\text { valve }\end{array}$ \\
\hline 1 & No. of Patients (\%) & $36(72 \%)$ & $14(28 \%)$ & \\
\hline \multirow{2}{*}{2} & $\begin{array}{c}\text { Mean } \\
\text { Serum }\end{array}$ & Morning & $\begin{array}{c}21.23 \\
(\mathrm{SD}=2.578)\end{array}$ & $\begin{array}{c}23.33 \\
(\mathrm{SD}=3.886)\end{array}$ & 0.1078 \\
\cline { 2 - 4 } & Cortisol & Evening & $\begin{array}{c}13.317 \\
(\mathrm{SD}=3.019)\end{array}$ & $\begin{array}{c}14.126 \\
(\mathrm{SD}=2.94)\end{array}$ & 0.3957 \\
\hline \multicolumn{6}{|c|}{ Table 2: Comparison of Mean Serum Cortisol Level between } \\
Single Leak and Multiple Leak on FFA \\
\hline
\end{tabular}

6. With respect to the pattern of leak on FFA, 39 cases (78\%) had ink-blot pattern, while 11 cases $(22 \%)$ had a smoke-stack pattern (Figure - 01, 02).

Mean serum cortisol levels compared between ink-blot pattern and smoke-stack patterns on FFA had no statistical significance in either sample $(p=0.3502$, Mor; $\mathrm{p}=0.0810$, Eve).

7. In our evaluation of CSR with OCT we found mean foveal thickness of $311.32 \mu \mathrm{m}(\mathrm{SD}=130.06)$ at presentation, which reduced to $278.9 \mu \mathrm{m}(\mathrm{SD}=80.649)$ at 3 months and $248.82 \mu \mathrm{m}(\mathrm{SD}=64.934)$ at 6 months. PED was associated in 13 cases accounting for $26 \%$. Subretinal fibrin was associated in 31 cases accounting for $62 \%$ (Figure - 03, 04).

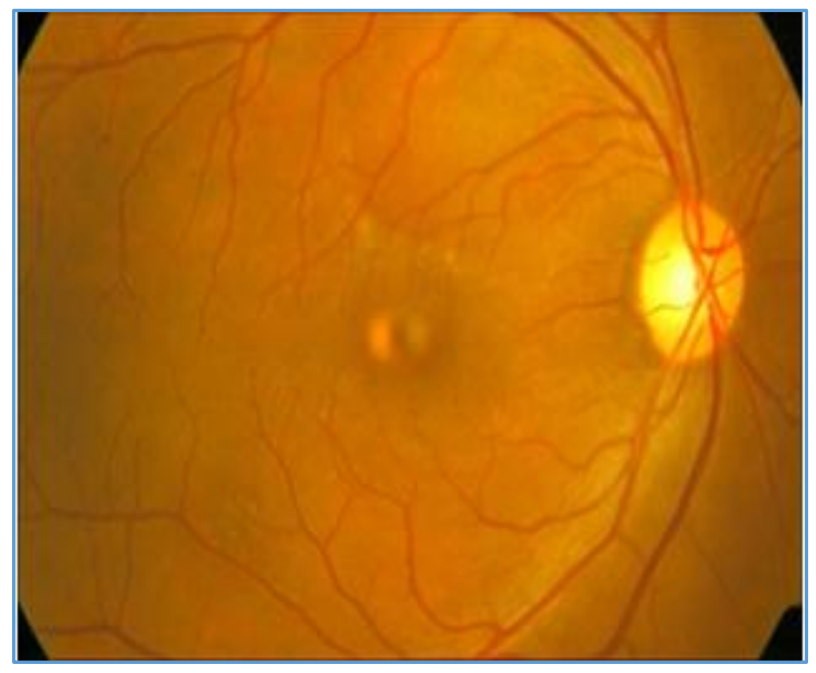



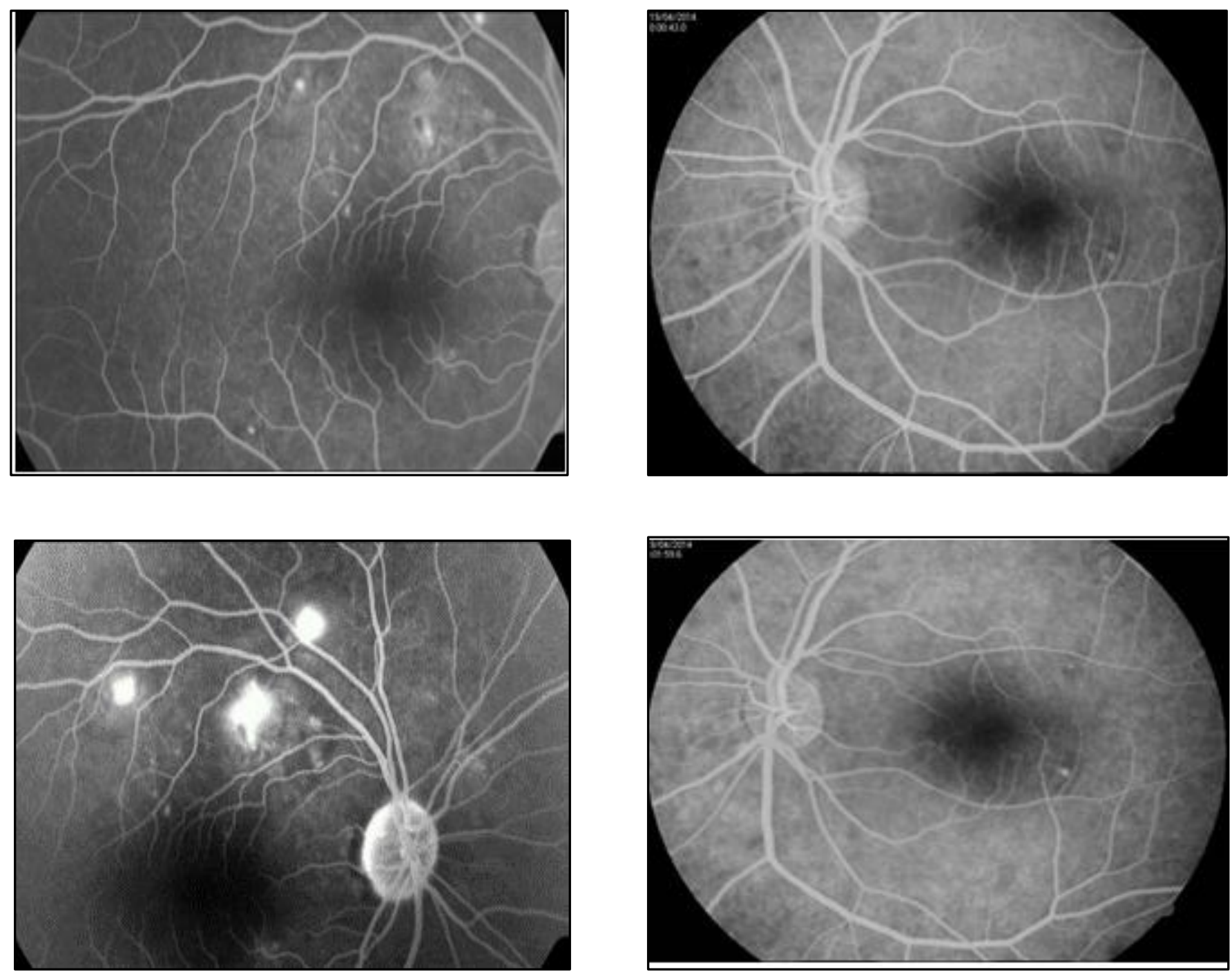

Fig. 1: OD Colour Fundus (Upper photo) of posterior pole showing Sensory Neural Detachment Superior to Fovea. Early A-V phase of FFA image (Middle photo) showing Multiple Point Leak along Superior Arcades. Late phase FFA image (Lower photo) showing Increase in Intensity and Area of Fluorescence at all sites. (Ink blot+multifocal)

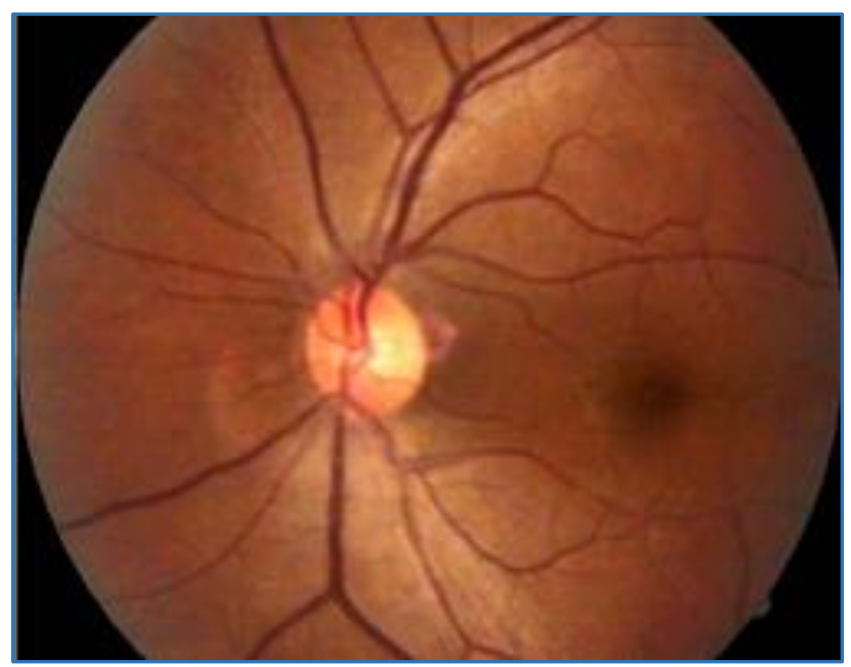

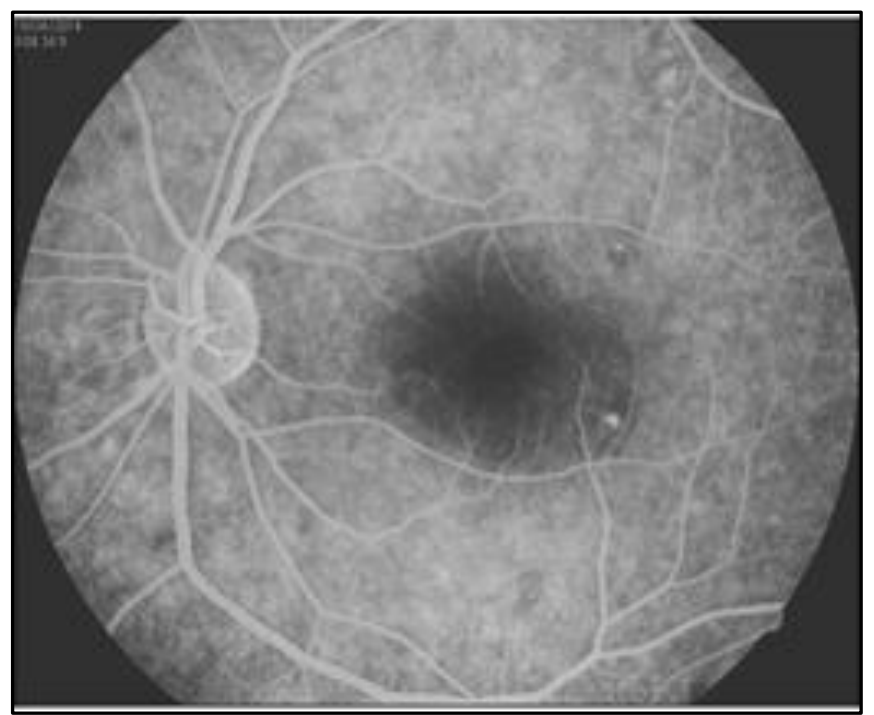

Fig. 2: OS Colour Fundus (Upper photo) of posterior pole showing Dull Foveal Reflex with Subretinal Fluid. Early A-V phase (43 sec) of FFA image (Middle photo) showing Early

Point Leak Infero-temporal to Fovea. Late phase FFA image (Lower 2 photos) showing Increase in Intensity and Area of Fluorescence (1:59 min. and 4:39 min. respectively) (Ink Blot Variant) 


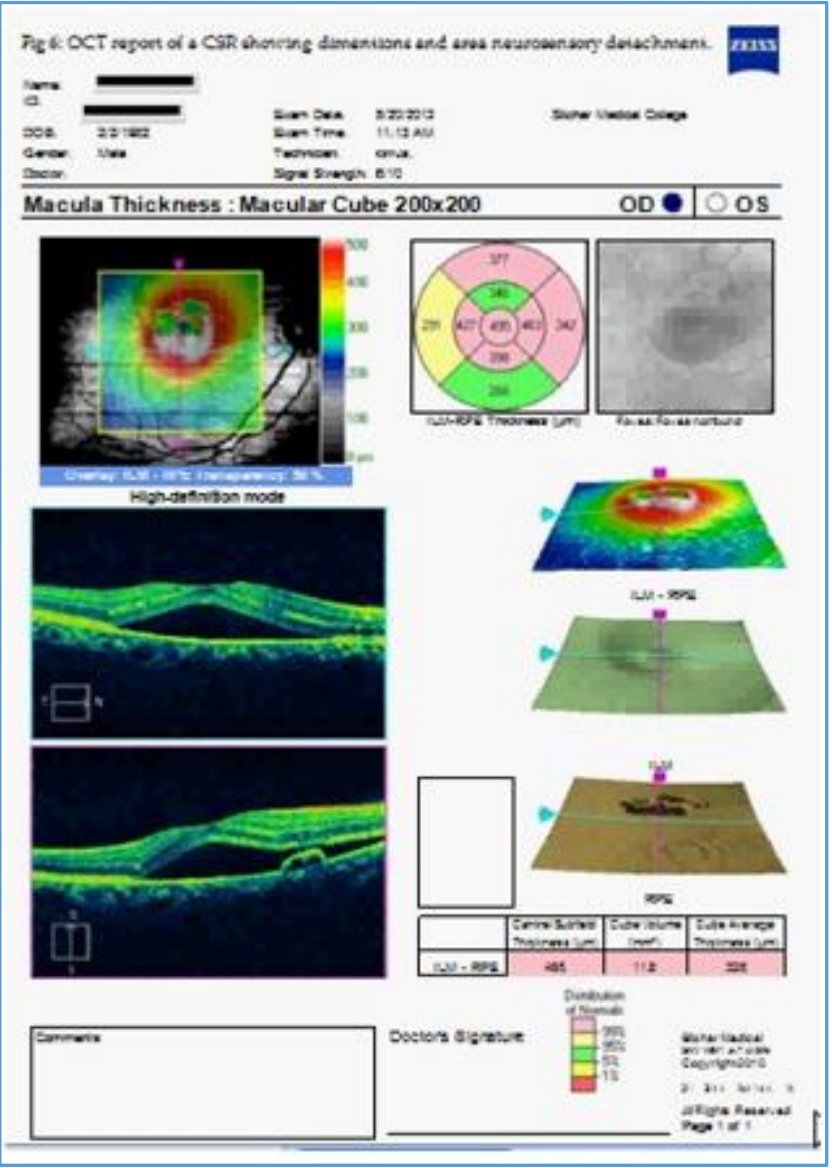

Fig. 3: OCT report of a CSR showing Dimensions and Area of Neurosensory Detachment

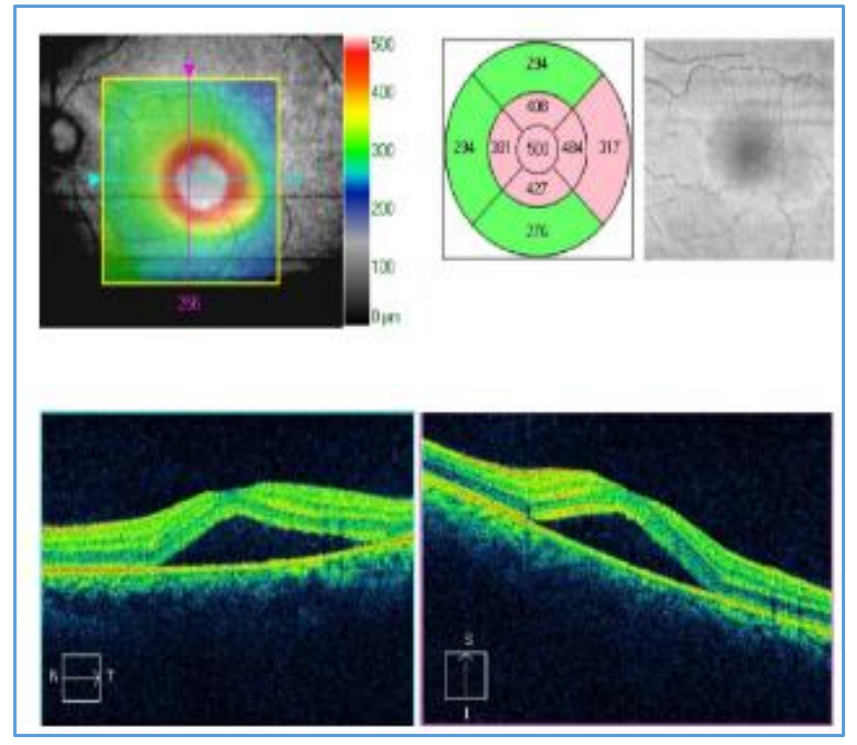

Fig. 4: OCT image (Upper row) showing Area of Scan at Macula (Macula Cube 200X200 Protocol), and Thickness of Macula in different quadrants. OCT images (Lower row) through Fovea showing Neurosensory Detachment with Clear Fluid Underneath. Scan passing from Nasal to Temporal (Lower right figure) and Inferior to Superior through Foveal Center (Lower left figure)

\section{DISCUSSION}

We undertook this study with the objective of evaluating a causal relation of steroids in CSR as well as to test this association with respect to different clinical parameters of CSR. The following outcomes establish a positive correlation between endogenous steroids and CSR, though its association with different clinical parameters of CSR varies.

Comparison of Demographic Profile between 2 groups and previous studies

\begin{tabular}{|c|c|c|c|c|}
\hline \multirow{2}{*}{ Parameters } & \multirow{2}{*}{$\begin{array}{l}\text { Cases } \\
(n=50)\end{array}$} & \multirow{2}{*}{$\begin{array}{c}\text { Controls } \\
(n=50)\end{array}$} & \multicolumn{2}{|c|}{ Zakir et al. } \\
\hline & & & Cases & Controls \\
\hline $\begin{array}{c}\text { Mean age } \\
\text { (yrs.) }\end{array}$ & $\begin{array}{c}34.3 \\
(\mathrm{SD}=5.319) \\
\end{array}$ & $\begin{array}{c}34.92 \\
(\mathrm{SD}=8.403)\end{array}$ & $37.1(9.7)$ & $35.7(9.2)$ \\
\hline $\begin{array}{c}\text { Sex } \\
\text { (male/female) }\end{array}$ & $43 / 7$ & $39 / 11$ & $22 / 23$ & $11 / 1$ \\
\hline
\end{tabular}

The demographic profile of cases and controls is well in accordance with the study by Zakir et al.

The mean age in our study for cases is $34.3 \pm 5.319$ yrs., while in controls the mean age is $34.92 \pm 8.403$. Zakir et al. 6 reported a mean of $37.1 \pm 9.7$ yrs. in cases and $35.7 \pm 9.2$ yrs. in controls.

Comparison of Serum Cortisol between 2 Groups and Previous Studies

\begin{tabular}{|c|c|c|c|c|c|}
\hline \multirow{2}{*}{$\begin{array}{l}\text { Sl. } \\
\text { No. }\end{array}$} & \multirow{2}{*}{$\begin{array}{l}\text { Study/ } \\
\text { Author }\end{array}$} & \multirow{2}{*}{$\begin{array}{l}\text { Cortisol } \\
\text { Sample }\end{array}$} & \multicolumn{3}{|c|}{ Serum Cortisol } \\
\hline & & & Cases & Controls & Pvalue \\
\hline \multirow{3}{*}{1} & \multirow{3}{*}{$\begin{array}{c}\text { Garg } \\
\text { et al. } \\
(1997) .^{7}\end{array}$} & $\begin{array}{l}\text { Morning } \\
(\mu \mathrm{g} / \mathrm{d} L)\end{array}$ & $\begin{array}{c}29.97 \\
(\mathrm{SD}=12.44) \\
\end{array}$ & $\begin{array}{c}18.76 \\
(\mathrm{SD}=8.26)\end{array}$ & $<0.001$ \\
\hline & & $\begin{array}{l}\text { Evening } \\
(\mu \mathrm{g} / \mathrm{dL})\end{array}$ & $\begin{array}{c}22.03 \\
(11.54)\end{array}$ & $\begin{array}{c}13.06 \\
(6.9)\end{array}$ & $<0.001$ \\
\hline & & $\begin{array}{c}24 \mathrm{hr} \text {. urine } \\
\text { cortisol } \\
\text { (mg/dL) } \\
\end{array}$ & $\begin{array}{c}11.01 \\
(S D=4.14)\end{array}$ & $\begin{array}{c}7.39 \\
(\mathrm{SD}=2.47)\end{array}$ & $<0.001$ \\
\hline \multirow{3}{*}{2} & \multirow{3}{*}{$\begin{array}{c}\text { Lalit } \\
\text { Verma } \\
\text { et al. } \\
(2001) .4\end{array}$} & $\begin{array}{l}\text { Morning } \\
(\mu \mathrm{g} / \mathrm{dL})\end{array}$ & $\begin{array}{c}\text { SSR: } \\
29.97 \pm 12.44 \\
\text { MSR: } \\
27.05 \pm 8.02 \\
\end{array}$ & $\begin{array}{c}\text { SSR: } \\
18.76 \pm 8.26 \\
\text { MSR: } \\
16.61 \pm 3.0\end{array}$ & $\begin{array}{l}<0.001 \\
\text { (Both) }\end{array}$ \\
\hline & & $\begin{array}{l}\text { Evening } \\
(\mu \mathrm{g} / \mathrm{dL})\end{array}$ & $\begin{array}{c}\text { SSR: } \\
22.03 \pm 11.54 \\
\text { MSR: } \\
16.45 \pm 3.53\end{array}$ & $\begin{array}{c}\text { SSR: } \\
13.06 \pm 6.9 \\
\text { MSR: } \\
11.53 \pm 1.94\end{array}$ & $\begin{array}{l}<0.001 \\
\text { (Both) }\end{array}$ \\
\hline & & $\begin{array}{l}24 \mathrm{hr} . \text { urine } \\
\text { cortisol } \\
(\mathrm{mg} / \mathrm{dL})\end{array}$ & $\begin{array}{c}\text { SSR: } \\
11.01 \pm 4.14 \\
\text { MSR: } \\
13.74 \pm 4.29\end{array}$ & $\begin{array}{c}\text { SSR: } \\
7.39 \pm 2.47 \\
\text { MSR: } \\
7.80 \pm 2.58\end{array}$ & $\begin{array}{l}<0.001 \\
\text { (Both) }\end{array}$ \\
\hline \multirow{2}{*}{3} & \multirow{2}{*}{$\begin{array}{c}\text { Zakir } \\
\text { et al. } \\
(2009){ }^{6}\end{array}$} & $\begin{array}{l}\text { Morning } \\
(\mu \mathrm{g} / \mathrm{dL})\end{array}$ & $17.94 \pm 6.142$ & $13.12 \pm 1.868$ & 0.002 \\
\hline & & $\begin{array}{l}\text { Evening } \\
(\mu \mathrm{g} / \mathrm{dL})\end{array}$ & 6.31 & 6.12 & $>0.05$ \\
\hline \multirow{2}{*}{4} & \multirow{2}{*}{$\begin{array}{c}\text { Present } \\
\text { Study }\end{array}$} & $\begin{array}{l}\text { Morning } \\
(\mu \mathrm{g} / \mathrm{dL})\end{array}$ & $\begin{array}{c}21.9986 \\
(\mathrm{SD}=3.852)\end{array}$ & $\begin{array}{c}19.386 \\
(\mathrm{SD}=(2.947)\end{array}$ & 0.001 \\
\hline & & $\begin{array}{l}\text { Evening } \\
(\mu \mathrm{g} / \mathrm{dL})\end{array}$ & $\begin{array}{c}13.5438 \\
(\mathrm{SD}=2.99)\end{array}$ & $\begin{array}{c}11.827 \\
(\mathrm{SD}=2.963)\end{array}$ & 0.0048 \\
\hline
\end{tabular}

There exists possible association between serum cortisol and acute CSR among different study groups as depicted above. In majority of previous studies, the cortisol levels measured at one time or different times in a single day have shown statistically significant higher values compared to age, sex matched controls. $4,6,7$

In our study out of 50 cases, 36 cases presented with single leak accounting for $72 \%$ of cases, while 14 cases (38\%) presented with multiple leaks. This proportion correlates 
well with Zakir et al. ${ }^{6}$ who reported single leak in 17 (74\%), and multiple leaks in 6 eyes (26\%) as well as Anna et al. ${ }^{8}$

\section{Comparison of OCT Features with Serum Cortisol}

The mean foveal thickness of cases at presentation was $311.32 \mathrm{~m}$ (SD=130.06), which resolved to $278.9 \mathrm{~nm}$ $(\mathrm{SD}=80.649)$ at 3 months and $248.82 \mathrm{~nm}(\mathrm{SD}=64.934)$ at 6 months. Moschos et al. ${ }^{9}$ found a mean foveal thickness of 303 $\mu \mathrm{m}$, which reduced to $213 \mu \mathrm{m}$ on regression. Our findings correlate with author's findings.

\section{CONCLUSION}

The present study titled "Clinical Study of Central Serous Retinopathy and its correlation with Serum Cortisol Levels" studied the causal role of endogenous steroids in Central Serous Retinopathy. The study compared the diurnal samples of mean serum cortisol levels in cases presenting with acute CSR with another group of age-sex-symptom matched patients taken as controls to prove or refute association. The study also evaluated association of steroids in varied clinical parameters of CSR.

The above study has well established a positive association of endogenous steroids in the causation of Central Serous Retinopathy, which has implications in the treatment strategies for the disease in future.

\section{REFERENCES}

1. Gregory L Skuta, Louis B Cantor, Jayne S Weiss. Basic and clinical science course; Section 12; Part II; Chapter 4. American academy of ophthalmology; 2011-2012;p 55.
2. Albert D. Jakobiec's principles practice of ophthalmology. Elsevier publications, Third Edition; Section 10; Chapter 142, 2008;2:1871.

3. Peyman GA, Bok D. Peroxidase diffusion in the normal and laser-coagulated primate retina. Invest Ophthalmol Vis Sci 1972;11(1):35-45.

4. Lalit Verma, Amitabh Purohit, Tewari HK, et al. A study of endogenous cortisol profile in patients with central serous retinopathy with single and multiple leaks. Indian Journal of Pharmacology 2001;33:96-9.

5. Laurence M Demers. The adrenal cortex. In: Carl A Burtis, Edward R Ashwood, David E Bruns, editor. Teitz textbook of clinical chemistry and molecular diagnostics. New Delhi: Elsevier publisher, 2006; $4^{\text {th }}$ ed:p 2016.

6. Zakir SM, Shukla M, Simi ZU, et al. Serum cortisol and testosterone levels in idiopathic central serous chorioretinopathy. Indian J Ophthalmol 2009;57(6):41922.

7. Garg SP, Dada T, Talwar D, et al. Endogenous cortisol profile in patients with central serous chorioretinopathy. Br J Ophthalmol 1997;81(11):962-4.

8. Anna Elias, Mahesh G, Savita Bhat, et al. Central serous chorioretinopathy: recurrence rate and factors affecting recurrence. Giridhar Eye Institute, Kochi, Kerala; 70th AIOC Proceedings, Cochin 2012.

9. Moschos M, Brouzas D, Koutsandrea C, et al. Assessment of central serous chorioretinopathy by optical coherence tomography and multifocal electroretinography. Ophthalmologica 2007;221(5):292-8. 